\title{
Seasonal dynamics of methane in the water column of two subtropical lakes differing in trophic status
}

\author{
Marinho, CC. ${ }^{\mathrm{a} *}$, Palma Silva, $C .^{\mathrm{b} *}$, Albertoni, EF. ${ }^{\mathrm{b}}$, Trindade, $C R .^{\mathrm{b}}$ and Esteves, $F A{ }^{\mathrm{a}}$ \\ aDepartamento de Ecologia, Laboratório de Limnologia, Instituto de Biologia, \\ Universidade Federal do Rio de Janeiro - UFRJ, \\ Ilha do Fundão, prédio CCS, bloco A, subsolo sala A0-008, CP 68020, CEP 21941-590 \\ ${ }^{\mathrm{b}}$ Laboratório de Limnologia, Instituto de Ciências Biológicas - ICB, \\ Universidade Federal de Rio Grande - FURG \\ *e-mail: clcamar@biologia.ufrj.br,dmbcps@furg.br
}

Received July 10, 2007 - Accepted November 21, 2007 - Distributed May 31, 2009

(With 1 figure)

\begin{abstract}
Alterations in methane concentration in the water column of aquatic systems is closely linked to the processes of production and consumption of this gas, i.e., methanogenesis and methanotrophy respectively. The aim of this research is to evaluate methane dynamics through diurnal variation in the concentration of this gas in the water column of two lakes differing in trophic status at the campus of Fundação Universidade do Rio Grande (FURG). In two sampling periods (November 2001 and July 2002) methane concentrations in the water column were significantly higher (3.66 and $0.41 \mu$ moles. $L^{-1}$, respectively) at Lago dos Biguás, with mesoeutrophic features when related to Lago Polegar (1.43 and $0.19 \mu$ moles. $\mathrm{L}^{-1}$, respectively) which has oligotrophic features. The higher methane concentrations were detected in November 2001 when higher temperature was also detected. The results highlighted the importance of trophic status as well as seasonality for the methane dynamics in these ecosystems.
\end{abstract}

Keywords: methane, eutrophication, methanogenesis, methanotrophy, subtropical lakes.

\section{Dinâmica sazonal do metano na coluna d'água de dois lagos subtropicais em diferentes estados tróficos}

\section{Resumo}

As alterações na concentração de metano na coluna d'água nos ecossistemas aquáticos estão intimamente ligadas aos processos de produção e consumo deste gás, ou seja, à metanogênese e metanotrofia, respectivamente. Esta pesquisa tem como objetivo determinar a dinâmica do metano através da variação diurna da concentração deste gás na coluna d'água em dois lagos de diferentes estados tróficos do Campus da Fundação da Universidade do Rio Grande (FURG). Nos dois períodos de coleta (novembro de 2001 e julho de 2002), as concentrações de metano foram significativamente maiores no lago dos Biguás (3,66 e 0,41 $\mu$ moles. $\mathrm{L}^{-1}$, respectivamente) de caráter mesoeutrófico em relação ao lago Polegar (1,43 e 0,19 $\mu$ moles. $L^{-1}$, respectivamente), de característica oligotrófica. Os maiores valores da concentração de metano na coluna d'água nos dois lagos foram observados no período de novembro de 2001, quando foram registrados também os maiores valores de temperatura. Estes resultados evidenciam tanto a importância do caráter trófico dos lagos quanto a sazonalidade em relação à dinâmica do metano nestes ecossistemas.

Palavras-chave: metano, eutrofização, metanogênese, metanotrofia, lagos subtropicais.

\section{Introduction}

Methane production (methanogenesis) is one of the most important processes of organic matter (OM) degradation in aquatic sediments (Schulz and Conrad, 1995), and depends fundamentally on the presence of substrate and anaerobiosis (Zinder, 1993). Methanogenesis in aquatic environments can be influenced by: temperature, eutrophication, presence of aquatic macrophytes, quantity and quality of organic matter among other factors (Singh, 2001; Pulliam, 1993; De Angelis and Scranton, 1993). In the presence of oxygen and methane as substrates, methanotrophic bacteria oxidize methane into $\mathrm{CO}_{2}$ (Whiting and Chanton, 1993). Due to the dynamics 
of these two gases, dissolved oxygen (DO) and methane, methanotrophy can vary significantly in aquatic systems. Ford et al. (2002) suggested that depending on the period of the year and the consequent water column stratification in a shallow floodplain lake, methanotrophy could be limited by the separation of DO and methane in the water column.

Artificial eutrophication in aquatic environments can have direct and indirect effects on both methanotrophy and methanogenesis. Among the direct effects, growth of methanogenic populations provided by the enhancement of nutrients loading and substrates, must be highlighted. The presence of substrate for methanogenesis depends on the previous decomposition of OM that produces electron donator compounds, such as acetate, for several anaerobic processes (Fenchel et al., 1998). As an indirect effect, there is a decrease in dissolved oxygen concentration, mainly in the hypolimnium, which can guarantee an anoxic environment favorable for methanogenics (Casper, 1992). Those effects are potentialized in eutrophic systems due to the high amounts of available organic matter which due to its labile feature, consumes dissolved oxygen and releases a great amount of substrate for methanogenesis. According to Huttunen et al. (2003), in research conducted in a eutrophic lake in Finland, the accumulation of methane during the winter happens due to the net dominance of methanogenesis over methanotrophy in this environment. At Lake Lugano, a eutrophic system located between Switzerland and Italy, through preliminary research on the methane cycle, the authors highlight the importance of methane in the carbon cycle and in the consumption of dissolved oxygen in the hypolimnium, through methanotrophy (Liu et al., 1996).

The campus of the Fundação Universidade Federal do Rio Grande - Carreiros - has a great number of small lakes, some of them of anthropogenic origin. These lakes, besides contributing to landscape improvement, also play the role as refuge to a great diversity of birds that change according to the season. Some of these environments can be considered as mesoeutrophic (Albertoni et al. 2007), due to the charge of nutrients from bird excrement and non-treated effluent disposal from the activity of restaurants on their margins.

The aim of this research is to evaluate the methane dynamics through diurnal variation in the concentration of this gas in the water column of two lakes at the Fundação Universidade do Rio Grande (FURG) campus. These two lakes are different in trophic status, Lago Polegar being considered as having oligotrophic features and Lago dos Biguás as a mesoeutrophic system.

\section{Materials and Methods}

\subsection{Study area}

Rio Grande is located at the morphic unity of the Rio Grande "restinga" or south barrier $\left(32^{\circ} 01^{\prime} 40^{\prime \prime} \mathrm{S}\right.$ and $\left.52^{\circ} 05^{\prime} 40^{\prime \prime} \mathrm{W}\right)$, together with the municipality of Santa Vitória do Palmar (Vieira and Rangel, 1988), on the southern littoral of Rio Grande do Sul state. The climate in the region is subtropical, with minimum temperature of $2{ }^{\circ} \mathrm{C}$ and mean of $13.4{ }^{\circ} \mathrm{C}$ in the winter. In the summer the minimum temperature is of $18{ }^{\circ} \mathrm{C}$ and mean of $22.6{ }^{\circ} \mathrm{C}$.

According to Vieira (1983), the process of geological evolution in this region does not present conditions for the establishment of big rivers and only small rivers and lakes constitute elements for a discussion of its hydrography. The features of these aquatic systems, as well as the linkage between them, can work as nutrient dispersal, and anthropogenic activities developed in one of them, can have negative repercussions in the others.

Among the studied systems, the Lago dos Biguás is the largest, with a superficial area of 2 ha and maximum depth of $1.8 \mathrm{~m}$. Lago Polegar, $1 \mathrm{~km}$ away, on the other hand, has an area of 1 ha and maximum depth of $1.5 \mathrm{~m}$. The lakes were built by the removal of sand for the construction of the campus. Lago dos Biguás was built about 25 years before Lago Polegar.

Lago dos Biguás has as a major feature the presence of different aquatic macrophytes, with the predominance of emergent and floating, with the possibility of excessive growth of Nymphoides indica (L.) Kuntze near to its margins and Pistia stratiotes Linnaeus at the end of winter and early spring. In relation to Lago Polegar, there is the presence of submerged aquatic macrophytes which denotes a higher transparency of the water column.

\subsection{Sampling}

Water samples were taken in November 2001 and July 2002, to determine dissolved methane concentration and abiotic variables in the water column of the two studied systems. Water samples for methane evaluation were collected in three different times throughout the day: 6:00 AM, 12:00 PM and 6:00 PM in November 2001 and 7:30 AM, 12:00 PM and 6:00 PM in July 2002. Depth, temperature, $\mathrm{pH}$, conductivity and dissolved oxygen were also evaluated. All measures were taken in the middle depth of the water column. Temperature was obtained with a mercury thermometer and DO was determined with a digital oxymeter (Digimed, model DMO-2) and conductivity and $\mathrm{pH}$ were determined with a conductivimeter (Leitfäligkeit, model LF37) and pHmeter (Ingold, model PH-206) respectively.

Dissolved nitrogen (DN), dissolved phosphorus (DP) and dissolved organic carbon (DOC) were also measured. DN concentration was obtained from acid digestion and posterior distillation according to the Kjedhal method modified by Mackereth et al. (1978). To evaluate DP concentration we used the method described by Golterman (1978) through the blue complex resulting from the formation of a reduced phosphomolybdate complex. DOC concentration was measured in a Carbon analyzer Shimadzu - TOC-5000. 


\subsection{Methane concentration}

Eight $\mathrm{mL}$ water samples were collected to determine methane concentration using plastic syringes and needles $(\mathrm{n}=5)$, and added to glass flasks of $12 \mathrm{~mL}$ closed with rubber stoppers, containing the equivalent of $20 \%$ (w/v) of $\mathrm{NaCl}$. The samples were taken to the laboratory and kept under refrigeration until the analyses were performed. Methane concentration was obtained using a gas cromatographer (Star 3400 - Varian Co., EUA) and the operation conditions were FID detector temperature $200{ }^{\circ} \mathrm{C}$, injector temperature $120^{\circ} \mathrm{C}$ and a $3 \mathrm{~m}$ Poropak- $\mathrm{N}$ column (80/100 mesh) at $85^{\circ} \mathrm{C}$ and $\mathrm{N}_{2}$ as the carrier gas.

\subsection{Data analyses}

The results of methane concentration in the water column, at different hours, were analyzed performing the non-parametric Kruskal-Wallis test, followed by the posthoc Dunn test. The Mann-Whitney test was performed to investigate differences between methane concentrations in the different sampling periods in both lakes. The significance level of $95 \%$ was used for all tests. The tests were performed using the GraphPad Instat 3.0 software (GraphPad Software Co.).

\section{Results}

There were no differences among temperature and conductivity values, in the water column of both lakes, dos Biguá and Polegar throughout the sampling day (Table 1). In relation to $\mathrm{DO}$ and $\mathrm{pH}$, the values showed a slight increase throughout the day, except for DO and $\mathrm{pH}$ at Lago Polegar, between the samples 7:30 PM and 12:00 PM in July 2002 and DO at Lago dos Biguás between the samples 12:00 PM and 6:00 PM in November 2001, that presented lower values.

Considering the two sampling periods, the observed differences seem to be mainly related to water temperature, since the temperature mean values were 23.3 ${ }^{\circ} \mathrm{C}$ in November, 2001 and $13{ }^{\circ} \mathrm{C}$ in July, 2002 (Table 1). Conductivity and $\mathrm{pH}$ values were also higher in November 2001, with mean values of $8.43 \mu{\mathrm{S} . \mathrm{cm}^{-1}}^{-1}$ and 7.71 at Lago Polegar, and $204.33 \mu \mathrm{S} . \mathrm{cm}^{-1}$ and 60.13 at Biguás Lake. In July 2002, mean pH values were 6.71 and 7.51 and conductivity were $52.07 \mu{\mathrm{S} . \mathrm{cm}^{-1}}^{1}$ and $170.27 \mu{\mathrm{S} . \mathrm{cm}^{-1}}^{-}$at lakes Polegar and Biguás, respectively. DO concentrations varied from $6.88 \mathrm{mg} . \mathrm{L}^{-1}$ (Lago Polegar in November 2001) to 11.24 mg.L $\mathrm{L}^{-1}$ (Lago dos Biguás in July 2002), mean values were usually higher than $8 \mathrm{mg} . \mathrm{L}^{-1}$. In general, DO concentrations were always higher at Lago dos Biguás than at Lago Polegar.

Nutrient concentrations were higher at Lago dos Biguás than at Lago Polegar except for DN in November 2001 , when the concentration was $14 \%$ higher than that at Lago dos Biguás (Table 2). The greater differences were observed for DP, which presented 6-times higher concentration in Lago dos Biguás than in Lago Polegar in July 2002 (8.38 and $1.68 \mu$ moles. $L^{-1}$, respectively). The smaller differences between both systems were detected in DOC concentration. In November 2001 and July 2002 at Lago dos Biguás the concentrations were 833 and $647 \mu$ moles. $L^{-1}$, respectively, around 5 and $12 \%$ higher than those for Lago Polegar (791 and $569 \mu$ moles.L ${ }^{-1}$ ) (Table 2). Considering the molar, low ratios C:P and N:P were detected at Lago dos Biguás.

Diurnal variation in methane concentration presented different patterns in both lakes (Figure 1). There were no significant differences at Lago Polegar considering the three sampling times ( $p>0.05$ ) (Figure 1), except for the sampling in November 2001 (12 pm) that was significantly higher than that at 6:00 PM $(\mathrm{p}<0.05)$. Methane concentration at Lago dos Biguás presented a significant decrease throughout the sampling day $(\mathrm{p}<0.05)$ (Figure 1$)$. The decrease in methane concentration in the water column between 6:00 AM and 6:00 PM in November 2001 and between 7:30 AM and 6:00 PM in July 2002 was from 4.84 to $2.06 \mu$ moles. $\mathrm{L}^{-1}$ and from 0.73 to $0.20 \mu$ moles.L $\mathrm{L}^{-1}$, equivalent to a decrease of 60 and $70 \%$, respectively.

A significant decrease in methane concentration was observed comparing the samples in November 2001 and

Table 1. Abiotic variables from lakes Polegar and Biguás in November 2001 and July 2002.

\begin{tabular}{|c|c|c|c|c|c|c|c|}
\hline Lakes & Sampling period & Time & Depth $(\mathbf{m})$ & DO (mg.L ( $\left.^{-1}\right)$ & Cond $(\mu S)$ & pH & Temperature $\left({ }^{\circ} \mathrm{C}\right)$ \\
\hline \multirow[t]{6}{*}{ Lago Polegar } & Nov 2001 & 6:00 AM & & 6.88 & 58.3 & 7.06 & 22 \\
\hline & & 12:00 PM & 0.8 & 8.36 & 60.5 & 7.63 & 24 \\
\hline & & 6:00 PM & & 8.44 & 61.6 & 8.44 & 24.5 \\
\hline & Jul 2002 & 7:30 AM & & 8.73 & 60.3 & 6.82 & 12 \\
\hline & & 12:00 PM & 1 & 9.08 & 44.8 & 6.54 & 13.6 \\
\hline & & 6:00 PM & & 10.65 & 51.1 & 6.76 & 13.5 \\
\hline \multirow[t]{6}{*}{ Lago dos Biguás } & Nov 2001 & 6:00 AM & & 7.83 & 199.4 & 7.89 & 22 \\
\hline & & 12:00 PM & 1 & 9.51 & 204 & 8.57 & 23.5 \\
\hline & & 6:00 PM & & 8.91 & 197.9 & 8.82 & 23.8 \\
\hline & Jul 2002 & 7:30 AM & & 7.71 & 165.2 & 7.02 & 11.8 \\
\hline & & 12:00 PM & 1.1 & 10.18 & 170.9 & 7.48 & 13.3 \\
\hline & & 6:00 PM & & 11.24 & 174.7 & 8.02 & 13.5 \\
\hline
\end{tabular}


Table 2. Nutrient concentration ( $\mu$ moles. $\mathrm{L}^{-1}$ ) in Lago Polegar and Lago dos Biguás in November 2001 and July 2002.

\begin{tabular}{clcccccc}
\hline Lakes & \multicolumn{1}{c}{ Period } & DOC & DN & DP & C:N & C:P & N:P \\
\hline Lago Polegar & November 2001 & 791 & 44.63 & 1.68 & 18 & 471 & 27 \\
& July 2002 & 569 & 39.81 & 1.39 & 14 & 409 & 29 \\
\multirow{2}{*}{ Lago dos Biguás } & November 2001 & 833 & 38.25 & 6.52 & 21 & 128 & 6 \\
& July 2002 & 647 & 53.09 & 8.38 & 12 & 77 & 6 \\
\hline
\end{tabular}
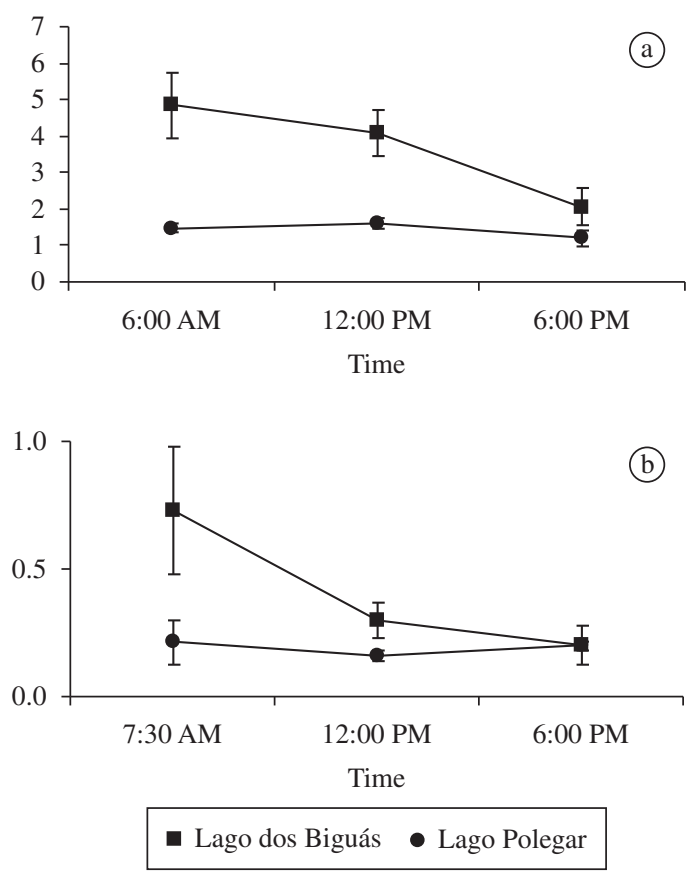

Figure 1. Diurnal variation of methane concentration in the water column at Lago Polegar and Lago dos Biguás in a) November 2001; and b) July 2002 .

July $2002(\mathrm{p}<0.05)$ at both lakes. Mean values related to daily concentration in November 2001 and July 2002 were $1.43 \pm 0.20$ and $0.19 \pm 0.03 \mu$ moles.L $L^{-1}$ at Lago Polegar and $3.66 \pm 1.44$ and $0.41 \pm 0.28 \mu$ moles. $L^{-1}$ at Lago dos Biguás, respectively. These results mean a reduction of $90 \%$ in methane concentration in the water column in July 2002 compared to November 2001. Except for the sample in July 2002 at 6:00 PM, all the other methane concentrations were significantly higher at Lago dos Biguás ( $\mathrm{p}<0.05)$. On average, methane concentration in November 2001 and July 2002 at Lago dos Biguás were 160 and $115 \%$ higher than at Lago Polegar.

\section{Discussion}

Due to the low depth of the Lakes Biguás and Polegar, wind action enables the constant mixture in the water column promoting homogenization and intense interaction among the different compartments, i.e, sediment, water and air. A similar pattern was observed by Esteves et al. (1988) considering DO, in a tropical shallow lagoon. According to the authors, due to the presence of the euphotic zone throughout the water column, primary production took place along the water column. In general, the enhancement of $\mathrm{pH}$ and $\mathrm{DO}$ observed in the present research must reflect the balance between production and respiration at these systems.

The increase of $\mathrm{pH}$ may be associated with the enhancement of phytoplanktonic photosynthetic activities, due to the alterations in $\mathrm{CO}_{2}$ concentration and its carbonated forms in the water column. It can be corroborated by the enhancement in DO concentration throughout the day, possibly reflecting on phytoplankton primary production as suggested by Carmouze (1994), that on a daily scale there is net rate production during the day and net mineralization in the night.

The differences between nutrients, mainly DP, and the molar ratios (Table 2), highlight the distinct trophic status between both lakes. These results are due to the nutrient input from bird excrement on Lago dos Biguás, besides the sewage disposal from human activities near the lake margins. Albertoni et al. (2007) observed a phytoplankton bloom at this lake during the summer. Lago Polegar can be classified as oligotrophic considering the low nutrient concentrations.

The decrease in methane concentration in the water column throughout the day at Lago dos Biguás can be explained by two factors: 1) decrease of methanogenic activity; and 2) enhancement of methanotrophic activity. A permanently oxygenized water column does not represent a limitation for methanotrophy on this compartment of the lakes. Thus, as methanogenesis need anaerobic conditions, since Biguás and Polegar are shallow lakes, light presence during the daytime can promote phytobenthic primary production, oxygenizing the sediment through photosynthetic activity (Nielsen et al., 1990). The enhancement of the oxidant feature in the sediment by phytobenthic oxygen production favors methanotrophy (Fenchel et al., 1998). In the present study, phytobenthic oxygen production may have promoted oxygenation of the sediment-water interface, inhibiting methanogenesis and stimulating methanotrophy in this microcosm. Since then, decreases in methane concentration were more significant in Biguás Lake, changes in the sediment-water interface can be closely related to higher nutrient concentration, which would stimulate phytoben- 
thic primary production and consequent enhancement of DO concentration during the period of higher light intensity. Besides, due to the presence of more labile $\mathrm{OM}$, of phtyoplanktonic origin, suggested by the low $\mathrm{C}: \mathrm{P}$ and $\mathrm{N}: \mathrm{P}$ ratios, (Table 2), and the higher nutrient concentrations at Lago dos Biguás, the decomposition process at night can stimulate a quick DO consumption at the water-sediment interface, which makes conditions more reducing, stimulating anaerobic processes (such as methanogenesis), rather than aerobic processes (such as methanotrophy).

Methanogenesis, like other biological processes in aquatic environments, is regulated by temperature (Sorrel and Boon, 1992; Boon and Mitchell, 1995). The difference of up to $10{ }^{\circ} \mathrm{C}$ observed during the sampling periods shows the importance of seasonality on methanogenesis at the Biguás and Polegar lakes. Rulik et al. (2000), in a study on the Sitka River in the Czech Republic, observed that methane concentration in pore water increases significantly with water column temperature. Another important issue is that with temperature increase, there is the intensification of OM decomposition, and higher substrate availability for methanogenesis. Schulz et al. (1997) observed the enhancement of acetate production due to temperature increase in experiments on Lake Constance sediment in Germany. The authors also observed that the conversion of $\left[2-{ }^{14} \mathrm{C}\right]$ acetate to ${ }^{14} \mathrm{CH}_{4}$ gradually enhances with temperatures up to $40{ }^{\circ} \mathrm{C}$. Thus, in the present research, the higher methane concentration in the water column in November 2001, both at lakes Polegar and Biguás, must be associated to the enhancement of methanogenic organism activities due to substrate availability.

The higher methane concentration at Lago dos Biguás, than that at Lago Polegar, can be explained by the differences in the lakes' trophic status. The higher nutrient concentration in the water column, mainly DP, and the presence of labile OM expressed by low N:P and C:P ratios, enable a greater methanogenic activity in the sediment of
Lago dos Biguás sediment. Studies in a subtropical hypereutrophic lake presented significantly positive correlations between methane emission to atmosphere and net primary production (Xing et al., 2005). Those results, as well as the ones presented here, confirm the importance of increases of phytoplanktonic biomass, a major source of autochthonous OM, which can in turn be converted, through decomposition, into substrates for methanogenesis (Huttenen et al., 2003). A higher availability of substrates, such as acetate, by phytoplanktonic OM decomposition, can favor increase in methane production (Schulz and Conrad, 1995). Another important effect of substrate availability increase is the possibility of minimizing competition for electron donators as acetate and $\mathrm{H}_{2} / \mathrm{CO}_{2}$, between methanogenesis and other anaerobic processes (Scholten et al., 2002; Scheid et al., 2003).

When observing methane concentration in other aquatic environments (Table 3), we can consider that the results from this study are in an intermediate range. Lago dos Biguás concentration is similar to lakes Diogo (a tropical lake), Biwa and Priest Pot (temperate lakes, mesoeutrophic and eutrophic features respectively). Both temperate lakes are subjected to water column stratification related to DO. So, the maximum methane concentration observed at these lakes, 3.04 and $4.8 \mu$ moles.L $L^{-1}$, respectively, represent hypolimnium anoxic conditions. This fact demonstrates the importance of the results in our study since they reflect that methane concentration near to the surface in a shallow environment is permanently oxygenized. Thus, even in conditions favorable for methanotrophy, concentration in the water column of both studied lakes, mainly Biguás, reflects considerable methanogenic activity.

Acknowledgements - The authors thank Marcos Paulo Figueiredo Barros and Albert Suhett for helpful comments that contributed to this manuscript. Thanks are due to Adriana de Melo Rocha, Albert Suhett and Rafael Guariento for improvements in the English. We are grateful to $\mathrm{CNPq}$ for financial support.

Table 3. Methane concentration in the water column of several aquatic environments.

\begin{tabular}{|c|c|c|}
\hline Place & {$\left[\mathrm{CH}_{4}\right]\left(\mu\right.$ moles. $\left.\mathrm{L}^{-1}\right)$} & Reference \\
\hline Biwa Lake, Japan & 0.004-3.04 & Murase et al. (2005) \\
\hline Mendota Lake, USA & $\sim 0.4-40$ & Harrits and Hanson (1980) \\
\hline Lugano Lake, Italy & $0.1-\sim 80$ & Liu et al. (1996) \\
\hline Grasil Lake, Fuchskahld, Germany & $3.7-14.7$ & Cham et al. (2002) \\
\hline Priest Pot Lake, UK & $0.31-4.8$ & Casper et al. (2000) \\
\hline Grosse Fuchskuhle Lake, Germany & $\begin{array}{l}\sim 9-\sim 100 \\
\sim 8-\sim 350\end{array}$ & Casper et al. (2003) \\
\hline Diogo Lake, SP, Brazil & $0.73-2.60$ & Ballester and Santos (2001) \\
\hline Coastal Lagoons, RJ, Brazil & $0.05-17.66$ & Marinho et al. (2004) \\
\hline Calado Lake, Amazonia, Brazil & $0.25-2.91$ & Engle and Melack (2000) \\
\hline Lago Polegar & $0.19-1.43$ & Present research \\
\hline Lago dos Biguás & $0.41-3.66$ & Present research \\
\hline
\end{tabular}




\section{References}

ALBERTONI, EF., PRELLVITZ, LJ. and PALMA-SILVA, C., 2007. Macroinvertebrate fauna associated with Pistia stratiotes and Nymphoides indica at subtropical lakes (SOUTH Brazil). Revista Brasileira de Biologia = Brazilian Journal of Biology, vol. 67, no. 3, p. 499-507.

BALLESTER, MVR. and SANTOS, JE., 2001. Biogenic gases $\left(\mathrm{CH}_{4}, \mathrm{CO}_{2}\right.$ and $\left.\mathrm{O}_{2}\right)$ distribution in a riverine wetland system. In FARIA, BM., FARJALLA, VF. and ESTEVES, FA. (Eds.). Aquatic microbial ecology in Brazil. Rio de Janeiro: PPGE-UFRJ. p. 21-31.

BOON, PI. and MITCHELL, A., 1995. Methanogenesis in the sediments of an Australian freshwater wetland: comparison with aerobic decay, and factors controlling methanogenesis. Federation of European Microbiological Societies - Microbiology Ecology, vol. 18, p. 175-190.

CARMOUZE, JP., 1994. O metabolismo dos ecossistemas aquáticos: fundamentos teóricos, métodos de estudo e análises químicas. São Paulo: Ed. Edgard Blücher Ltda; FAPESP. 253p.

CASPER, P., 1992. Methane production in lakes of different trophic state. Archiv für Hydrobiologie, vol. 37, p. 149-154.

CASPER, P., CHAM, OC., FURTADO, ALS. and ADAMS, DD., 2003. Methane in an acidic bog lake: the influence of peat in the catchment on the biogeochemistry of methane. Aquatic Sciences, vol. 65 , p. 36-46.

CASPER, P., MABERLY, SC., HALL, GH. and FINLAY, BJ., 2000. Fluxes of methane and carbon dioxide from a small productive lake to the atmosphere. Biogeochemistry, vol. 49, p. 1-19.

CHAM, OC., WOLF, M., HEPPERLE, D. and CASPER, P., 2002. Methanogenic archael community in the sediment of an artificially partitioned acidic bog lake. Federation of European Microbiological Societies - Microbiology Ecology, vol. 42, p. 119-129.

De ANGELIS, MA. and SCRANTON, MI., 1993. Fate of methane in the Hudson River and estuares. Global Biochemistry, vol. 7, no. 3, p. 491-507.

ENGLE, D. and MELACK, JM., 2000. Methane emissions from an Amazon floodplain lake: enhanced release during episodic mixing and during falling water. Biogeochemistry, vol. 51, p. 71-90.

ESTEVES, FA., BOZELLI, RL., CAMARGO, AFM., ROLAND, F. and THOMAZ, SM., 1988. Variação diária (24) de temperatura, OD, pH e alcalinidade em duas lagoas costeiras do estado do Rio de Janeiro e suas implicações no metabolismo destes ecossistemas. Acta Limnologia Brasiliensia, vol. 2, p. 99-127.

FENCHEL, T., KING, GM. and BLACKBURN, TH., 1998. Bacterial biogeochemistry. 2 ed. California and London: Academic Press. 307p.

FORD, PW., BOON, PI. and LEE, K., 2002. Methane and oxygen dynamics in a shallow floodplain lake: the significance of periodic stratification. Hydrobiologia, vol. 485, p. 97-110.

GOLTERMAN, HL., CLYMO, RS. and OHNSTAD, MAM., 1978. Methods of physical and chemical analysis of freshwaters. Oxford: Blackwell. 315p.

HARRITS, SM. and HANSON, RS., 1980. The role of methane in internal carbon cycling in Lake Mendota during summer stratification. Limnology and Oceanography, vol. 25, no. 2, p. $357-360$.

HUTTUNEN, JT., ALM, J., LIIKANEN, A., JUUTINEN, S., LARMOLA, T., HAMMAR, T., SILVOLA, J. and MARTIKAINEN, PJ., 2003. Fluxes of methane, carbon dioxide and nitrous oxide in boreal lakes and potencial anthropogenic effects on the aquatic greenhouse gas emissions. Chemosphere, vol. 52, p. 609-621.

LIU, R., HOFMANN, A., GÜLAÇAR, FO., FAVARGER, PY. and DOMINIK, J., 1996. Methane concentration profiles in a lake with a permanently anoxic hypolimnion (Lake Lugano, SwitzerlandItaly). Chemical Geology, vol. 133, p. 201-209.

MACKERETH, FJH., HERON, J. and TALLING, JF., 1978. Water analysis: some revised methods for limnologists. Cumbria; Dorset: Freshwater Biological Association; Scientific Publication no. 36.

MARINHO, CC., FONSECA, ALS., MINELlO, M. and ESTEVES, FA., 2004. Resultados e perspectivas sobre o estudo do metano nas Lagoas Costeiras da Restinga de Jurubatiba e na Lagoa Imboassica na Região Norte do Estado do Rio de Janeiro. In ROCHA, CFD., ESTEVES, FA. and SCARANO, FR. (Eds.). Pesquisas ecológicas de longa duração na Restinga de Jurubatiba: ecologia, história natural e conservação. São Carlos: Rima. 475p.

MURASE, J., SAKAI, Y., KAMETANI, A. and SUGIMOTO, A., 2005. Dinamics of methane in mesotrophic lake Biwa, Japan. Ecology Research, vol. 20, p. 377-385.

NIELSEN, LP., CHRISTENSEN, PB., REVSBECH, NP. and SØRENSEN, J., 1990. Denitrification and photosynthesis in stream sediment studied with microsensor and whole-core techniques . Limnology and Oceanography, vol. 35, no. 5, p. 1135-1144.

PULLIAM, WM., 1993. Carbon dioxide and methane exports from a southeastern floodplain swamp. Ecological Monographs, vol. 63 , no. 1, p. $29-53$.

RULIK, M., CAP, L. and HLAVACOVA, E., 2000. Methane in the hyporeic zone of a small lowland stream (Sitka, Czech Republic). Limnologica, vol. 30, no. 4, p. 359-366.

SCHEID, D., STUBNER, S. and CONRAD, R., 2003. Effects of nitrate- and sulfate-amendment on the methanogenic populations in rice root incubations. Federation of European Microbiological Societies -Microbiology Ecology, vol. 43, p. 309-315.

SCHOLTEN, JCM., BODEGON, PM., VOGELLAR, J., ITTERSUM, A., HORDIJK, K., ROELOFSEN, W. and STAMS, AJM., 2002. Effect of sulfate and nitrate on acetate conversion by anaerobic microorganisms in a freshwater sediment. Federation of European Microbiological Societies Microbiology Ecology, vol. 42, p. 375-385.

SCHULZ, S. and CONRAD, R., 1995. Effect of algal deposition on acetate and methane concentrations in the profundal sediment of a deep lake (Lake Constance). Federation of European Microbiological Societies -Microbiology Ecology, vol. 16, p. $251-260$

SCHUlZ, S., MATSUYAMA, H. and CONRAD, R., 1997. Temperature dependence of methane production from different precursors in a profundal sediment (Lake Constance). Federation of European Microbiological Societies - Microbiology Ecology, vol. 22, p. 207-213.

SINGH, SN., 2001. Exploring correlation between redox potential and other edaphic factors in field and laboratory 
conditions in relation to the methane efflux. Enviroment International, vol. 27, p. 265-274.

SORREL, BK. and BOON, PI., 1992. Biogeochemistry of billabong sediments. II. Seasonal variations in methane production. Freshwater Biology, vol. 27, no. 3, p. 435-445.

VIEIRA, EF. and RANGEL, SRS., 1988. Planície costeira do Rio Grande do Sul: geografia física, vegetação e dinâmica sócio-demográfica. Porto Alegre: Sagra. 256p.

VIEIRA, EF., 1983. Rio Grande: geografia física, humana e econômica. Porto Alegre: Sagra. 158p.
WHITING, GJ. and CHANTON, JP., 1993. Primary production control of methane emission from wetlands. Nature, vol. 364, p. 794-795.

XING, Y., XIE, P., YANG, H., NI, L., WANG, Y. and RONG, K., 2005. Methane and carbon dioxide fluxes from a shallow hypereutrophic subtropical lake in China. Atmospheric Environment, vol. 39, p. 5532-5540.

ZINDER, SH., 1993. Physiological ecology of methanogens. In FERRY, JG. (Ed.). Methanogenesis. New York and London: Chapman and Hall. p. 253-303. 
